\title{
THE ROLE OF THE IFO BUSINESS CLIMATE INDICATOR AND ASSET PRICES IN GERMAN MONETARY POLICY
}

\author{
ELMER STERKEN
}

CESIFO WORKING PAPER NO. 1204

CATEgORY 6: MONETARY POLICY AND INTERNATIONAL FinanCE

MAY 2004

Presented At CESifo CONFERENCE “ACADEMiC Use of Ifo SuRVEy DATA"

DECEMBER 2003

An electronic version of the paper may be downloaded

- from the SSRN website:

www.SSRN.com

- from the CESifo website:

www.CESifo.de 


\title{
THE ROLE OF THE IFO Business ClimATE INDICATOR AND ASSET PRICES IN GERMAN MONETARY POLICY
}

\begin{abstract}
We analyze the role of forward-looking indicators, like the IFO business climate indicator and asset prices, in German monetary transmission. We show that the use of both the IFO indicator and asset prices improves the performance and interpretation of a Vector AutoRegression (VAR) model of German monetary transmission. First, we show that the Bundesbank responded more intensively to changes in the IFO indicator than to changes in GDP. Secondly, we address the role of housing and equity prices. We demonstrate that especially housing prices help to give a more accurate description of the recent history of German monetary policy.

JEL classification: C22, C53, C82.
\end{abstract}

Keywords: monetary transmission, IFO business climate survey indicator, house prices, equity prices.

\author{
Elmer Sterken \\ Department of Economics \\ University of Groningen \\ P.O. Box 800 \\ 9700 AV Groningen \\ The Netherlands \\ e.sterken@eco.rug.nl
}

I thank Bob Chirinko and Leo de Haan for sharing their knowledge, Jan Jacobs for helpful remarks and especially Frank Westermann for essential suggestions. This paper is sponsored by CESifo. I gratefully acknowledge the support by Timo Wollmershäuser and Jan-Egbert Sturm. 


\section{Introduction}

No matter whether an instrument or a targeting rule is used, monetary policy makers are concerned about the short-run future development of e.g. inflationary expectations and/or the expected output gap. The forward looking nature of monetary policy is widely acknowledged in theory (see Walsh, 2003), but still creating problems in empirical analysis. In most of the nowadays popular time-series studies (see Christiano, et al., 1999) it has become apparent that it is hard to use reliable indicators of expected output and price developments. As Orphanides (2001) argues, the use of e.g. realtime output data can change for instance the role and interpretation of a Taylor rule in the U.S. case. ${ }^{1}$ In this paper we present a double answer to the forward looking problem problem. We will use a business cycle indicator as a proxy to measure current real economic activity. Moreover, we will use asset prices as indicators of expectations of all future economic variables. The goal of the paper is twofold. First, we want to illustrate that misspecification issues are less likely to occur if one takes these kind of forward looking variables into account. Secondly, we will show that central banks do indeed respond to information embedded in these forward-looking variables. This sheds some new light on the interpretation of monetary policy.

In the end the effectiveness of monetary transmission, by whatever channel, depends on the rigidity of prices and wages and on the transmission into real expenditure categories. Traditionally, the so-called interest rate channel is held responsible for transmission of monetary policy shocks. Nowadays the working of the whole financial system is believed to be relevant. Due to informational problems the credit market has a special role in propagating monetary shocks (see Bernanke and Blinder, 1988). But revaluation of all assets and liabilities (resulting in net wealth positions) seems to determine the ultimate impact. The financial structure, like described by Tobin in his general equilibrium view on the financial sector (see e.g. Brainard and Tobin, 1968), is crucial in transmission (see also the financial accelerator approach by Bernanke et al., 1999).

As Lettau et al. (2002) show for the US, equity, housing, and liquidity are considered to be the three key financial markets in transmission (apart from the money and credit markets). Liquidity in various forms is essential to consumption and investment decisions (but we will not elaborate on this well-developed literature here). Lettau et al. argue that the housing market is central in monetary transmission. An interest rate increase will increase the costs of mortgages. The fall in demand for housing will reduce the collateral value of existing houses, lower borrowing capacity for its owners and so start a downturn in a credit cycle (see Kiyotaki and Moore, 1999).

\footnotetext{
${ }^{1}$ Adema (2003) on the other hand illustrates that this problem is less relevant for the euro area, because the European Central Banks focuses more on the control of inflation.
} 
The direct wealth effects of housing market crashes are well known and by far more substantial than any other revaluation effect. Equity markets on the other hand have a leading role in expected future growth and inflation forecasting. The informational contents of equity is relevant to forwardlooking decisions. As Bernanke (2003) argues monetary economists need to understand how strong monetary policy changes affect equity prices (the equity price-interest rate elasticity is believed to be about 3 to 6 for the US) and more important, why equity prices are influenced. With this knowledge one can analyze transmission of asset price changes into real decisions and infer consequences for monetary policy.

Asset prices contain more information than any other economic variable: e.g. equity prices are believed to signal future business cycle developments. Until the last recession in 2001 in the U.S., the SP-500 has shown to be a leading indicator of GDP-growth. This leading property of asset prices has two major consequences. First, monetary authorities will use asset price information to derive inflationary and output gap expectations. The Bundesbank was believed to pursue a monetary strategy focused on inflation (see Bernanke and Mihov, 1997), so would have been eager to follow asset price inflation. Secondly, private agents will use the information embedded in asset prices (or revaluations) into their decision making process. So the leading informational contents of asset prices might change our view on the effectiveness of monetary policy. If we observe that central banks care about expectations, we should also incorporate growth expectations. Are central bankers interested in lagged real growth or output gaps in steering monetary policy or do they take care of expected business cycle developments? We advocate the latter in this paper and combine the role of the role of asset prices and expected output developments. It is most likely that business cycle indicators will not be determined by asset price bubbles (like in 2001 in the U.S.) and will therefore be valuable contributors in our analysis.

We take Germany as an example, because of two main reasons. First of all, the German financial system and the role of the housing market are special. Germany is known for being a bank-based economy (see e.g. Kakes and Sturm, 2002). This leads to the expectation that housing price transmission maybe important. With the Netherlands, Germany has the highest share of mortgage loans to GDP in the EU. This could lead to vulnerability to interest rate shocks. Moreover, the term of the mortgage contracts is typically long ( 25 to 30 years, as in Austria and The Netherlands). On the other hand the owner occupation rate in Germany is relatively low (40 percent, while 63 for the EU) while the private rental occupation rate is high. So it remains an empirical problem to establish the precise impact of house prices. Secondly, we take Germany as an example since it has a consistent historical experience in using business cycle indicators. We turn back to this issue later on in discussing the data we use.

There are several interesting issues to be addressed. First, how is the 
monetary transmission mechanism affected by asset prices? Does neglecting asset price developments lead to the 'wrong' conclusions with respect to output and inflation-sensitivity to monetary policy changes? Secondly, how big is the impact of asset price shocks on GDP? How should we cope with a contemporaneous measurement of GDP, knowing that official publication of GDP lags at least one year? And thirdly, did monetary authorities respond to asset price changes in the past? We don't go into the problem how central banks should respond to asset price changes. The latter problem requires the specification of a social welfare function, which is out of scope of this paper.

In the next section we very shortly describe the theoretical context of our study. Our main argument in Section 2 is that it is generally believed that positive asset price shocks should stimulate real expenditure. In Section 3 we very briefly compare the German housing and equity markets to those in France, Italy, Japan, the UK and US. We show that housing is relatively important in Germany. We proceed in Section 4 by reviewing the literature on Vector AutoRegression (VAR) models. We describe the methodology, the major results on monetary policy identification, and VAR-models that focus on Germany and/or asset prices. Next we specify a basic VAR model of the German economy. We show that including the IFO-indicator instead of real GDP growth in the base model leads to a more interesting interpretation of monetary policy. Next we show that including asset prices also provides a richer view. We compare the major findings of the models in terms of structural factorizations of impulse response functions and variance decompositions of the interest rate equation (which we assume to be the monetary policy rule). In Section 6 we summarize and conclude.

\section{Theory}

The literature on the theory of monetary transmission and monetary policy rules is enormous (see Walsh, 2003). For our paper two strands of this literature are relevant. First, the role of the measurement of real activity. Secondly, the role of asset prices. In the discussion on monetary policy rules measurement of expected real activity is one of the recent issues of debate. Orphanides (2001) discusses the role of so-called real-time indicators of output gaps and concludes for the U.S. that using real-time data matters in designing rules. Sauer and Sturm (2003) and Adema (2003) do not find that the use of real-time data matters to the ECB's monetary policy design. In general though, the literature is convinced of the forward-looking nature of monetary policy (see Clarida and Gertler, 1997). So including more timely measures of output or output gaps is necessary in designing rules.

Our second theoretical item, the role of asset prices in monetary transmission, deserves a little more attention. We discuss the role of asset prices 
in general, and house and equity prices in particular. Housing and equity differ in two important aspects. First, housing provides direct consumer services and enters the utility function (see e.g. Aoki et al., 2002). Second, price changes of housing can be observed less frequently. This implies that the informational content of housing prices is typically less than the one carried by equity.

Standard classical monetary theory focuses on the interest rate channel. In the tradition of Wicksell (1907), a lower banking rate (below the natural rate of interest) has an impact on spending (investment in particular) which will lead to higher output if prices are sticky. Starting with Bernanke and Blinder (1988), the credit channel has become an important second line of transmission. Information asymmetries in the credit market will lead to equilibrium rationing and so transmit initial monetary shocks via credit to output. In the same spirit Bernanke and Gertler (1995) extended the credit channel to a credit view by allowing the so-called financial accelerator: revaluation of assets affects spending.

How should we treat asset price changes in this respect? First, since asset prices reflect expected discounted future payoff streams, an adjustment of a (stochastic) discount factor will lead to a revaluation. To what extent precisely monetary policy changes affect these stochastic discount factors (are risk premia embedded?) is unknown, but a positive shock to money market rates is likely to have a negative direct revaluation of assets. If asset prices change, how will this influence real expenditure? Here we can think of four basic mechanisms (see Chirinko et al., 2003).

First, there is the classical Modigliani life-cycle model, which leads to the wealth channel. Higher asset values will increase lifetime wealth and therefore positively affect e.g. private consumption. It is an empirical matter to what extent various assets will (temporarily) affect lifetime wealth. Equity price changes might be transitory and interpreted in this way, while house price changes for instance might be considered to be more permanent (or sticky at least). Moreover, an asset like housing provides direct consumer services and enters a utility function (see e.g. Aoki et al., 2002). If asset components and consumption are substitutes, an increase in e.g. housing wealth might lead to substitution out of consumption. So the wealth channel is not completely clear about the impact of asset price changes on real expenditure.

Secondly, in relation to the financial accelerator, we have the balance sheet channel. Both consumers and firms can be exposed to financing constraints, due to informational problems. If external finance is more expensive than internal sources of finance it is likely that financial structure of households or firms is relevant. Positive revaluation of assets can alleviate these constraints (see Hubbard, 1998).

Third, positive shocks to e.g. equity prices might lower the equity financing costs (and to some extent the same argument holds for housing). If the 
current equity price falls below the fundamental value, equity financing gets cheap. This so-called equity-financing channel might not lead to a positive impact on real expenditure, if managers use the proceeds from emissions to invest in financial transactions. So the sign of the equity channel is not clear a priori.

Fourth, in the spirit of Brainard and Tobin (1968) there might be an allocation channel. If there is an initial shock to some asset price, imperfect substitutable assets will be exchanged, leading to revaluation of other assets. It will be hard to align market and fundamental values, which might lead to misallocation. This misallocation might even stretch out to real investment.

The bottomline of these four channels is that it is likely that there will be positive impact of a policy interest rate decrease, but there is no absolute guarantee. It remains an empirical issue to what extent asset price changes will affect real expenditure.

\section{The German equity and housing markets in a birds-eye view}

The German financial system is different from its U.K. and U.S. equivalents (see Allen and Gale, 2000). We don't discuss this general feature in detail, but provide Table 1 with some basic key indicators for France, Germany, Italy, Japan, the U.K. and U.S. (from the World Bank source on Financial Structure Indicators). We can observe the relative overhang to bank loans in Germany opposed to the more equity markets based Anglo-Saxon economies. Knowing this general feature of the German financial system, we provide some more detail on housing and equity markets. Table 2 provides information of the relative shares of equity and housing values in a subset of the countries (using our database EUROMON, produced by De Nederlandsche Bank). Here we see that housing wealth is relatively large in Germany. Equity markets are relatively larger by this measure in the UK and US (as one would expect from Table 1). The wealth components are computed from the capital stock of the corporate sector and the general stock price index for the equity variable and the stock of owner occupied houses and the general housing price index for the housing variable. From Table 2 we conclude that the role of the housing market is relatively important in the German case.

For both markets it is interesting to know more about ownership, because ownership is relevant to the effectiveness of transmission. For the equity market it is hard to get an idea of the ownership structure though. La Porta et al. (1999) provide information on the ownership of listed firms for both medium-sized and large publicly traded firms. We give the data for the six economies of interest in Table 3. From this table it can be seen that German is not that publicly owned as in market-based economies. Medium- 
Table 1: Financial system indicators

\begin{tabular}{lllllll}
\hline & France & Germany & Italy & Japan & U.K. & U.S. \\
\hline Private credit by deposit money banks to GDP & 80.9 & 93.6 & 53.1 & 102.4 & 79.1 & 64.3 \\
Concentration of banks & 34.5 & 38.6 & 30.6 & 18.3 & 45.0 & 21.1 \\
Net Interest Margin & 3.3 & 2.9 & 3.9 & 2.0 & 2.3 & 4.4 \\
Stock market capitalization to GDP & 22.6 & 19.1 & 13.6 & 68.0 & 82.6 & 64.9 \\
Stock market total value traded to GDP & 11.1 & 18.3 & 6.5 & 34.7 & 38.0 & 46.0 \\
Stock market turnover ratio & 39.7 & 85.7 & 38.8 & 48.6 & 40.3 & 62.8 \\
Private bond market capitalization to GDP & 42.5 & 48.1 & 30.4 & 43.2 & 16.6 & 79.5 \\
Public bond market capitalization to GDP & 32.7 & 22.9 & 91.2 & 52.3 & 30.2 & 56.1 \\
\hline
\end{tabular}

Table 2: Housing and equity wealth indicators (percentages of GDP)

\begin{tabular}{lllllll}
\hline & France & Germany & Italy & Japan & U.K. & Japan \\
\hline Housing & 377.0 & 686.4 & 514.9 & 309.1 & 407.0 & 426.4 \\
Equity & 529.9 & 532.1 & 547.5 & 374.3 & 602.4 & 616.4
\end{tabular}

Source: EUROMON Database, De Nederlandsche Bank. The housing wealth is computed as the rebuilding value of the stock of private owner occupied houses (assuming a lifetime of 50 years). The equity wealth is computed as the value (traded and non-traded) of the capital stock (not owned by debt-holders). Here we assume an annual depreciation of 6 percent per year. The figures are averages over 1978-2000. 
Table 3: Equity ownership indicators (fractions)

\begin{tabular}{lllllll}
\hline & France & Germany & Italy & Japan & U.K. & U.S. \\
\hline Medium-sized firms & & & & & & \\
Widely held & 0 & 0.1 & 0 & 0.3 & 0.6 & 0.9 \\
Family & 0.5 & 0.4 & 0.6 & 0.1 & 0.4 & 0.1 \\
State & 0.2 & 0.2 & 0 & 0 & 0 & 0 \\
Widely held financial & 0.2 & 0.1 & 0 & 0 & 0 & 0 \\
Widely held corporate & 0 & 0.1 & 0.1 & 0 & 0 & 0 \\
Miscellaneous & 0.1 & 0 & 0.3 & 0.6 & 0 & 0 \\
Large publicly traded firms & & & & & & \\
Widely held & 0.6 & 0.5 & 0.2 & 0.9 & 1 & 0.8 \\
Family & 0.2 & 0.1 & 0.15 & 0.05 & 0 & 0.2 \\
State & 0.15 & 0.25 & 0.4 & 0.05 & 0 & 0 \\
Widely held financial & 0.05 & 0.15 & 0.05 & 0 & 0 & 0 \\
Widely held corporate & 0 & 0 & 0.1 & 0 & 0 & 0 \\
Miscellaneous & 0 & 0 & 0.1 & 0 & 0 & 0 \\
\hline
\end{tabular}

Source: La Porta et al. (1999).

sized firms are owned by controlling families. Large firms are relatively more owned by financial institutions and the government.

Finally, we provide some institutional data on the housing market (see Giuliodori, 2003) in Table 4. We provide information on the ownership structure in the upper panel. We can observe that relatively few houses are occupied by owners in Germany and more rental activity is observed. In principle this will complicate a housing price channel, but it is not said that house-owners will not transmit revaluation into rental tariffs. In the lower panel we give some mortgage system information. Germany has a relatively large fraction of mortgage loans, the contracts are typically longer, but the mortgage loan costs are comparable to the foreign equivalents.

\section{Literature on Vector Autoregression Models}

In this section we review the relevant literature on Vector Autoregression (VAR) models. We start with a discussion of the most important contributions in this field. Next we discuss how monetary policy shocks are identified in VAR-models, and review the role of asset prices. Finally we give an overview of VAR-models of the German economy. 
Table 4: House market indicators

\begin{tabular}{lllll}
\hline Variable & France & Germany & Italy & U.K. \\
\hline Housing tenure structure & & & & \\
Owner occupation rate & 54 & 40 & 75 & 67 \\
Social rental occupation rate & 21 & 20 & 3 & 23 \\
$\begin{array}{l}\text { Private rental occupation rate } \\
\text { Other }\end{array}$ & 8 & 40 & 22 & 10 \\
Mortgage systems & 0 & 0 & 0 \\
Residential mortgages/GDP & 21 & 51 & 7 & 57 \\
Typical term & 17.5 & 27.5 & 10 & 25 \\
Typical Loan-to-Value ratio & 75 & 70 & 50 & 92.5 \\
Transaction costs & 7.5 & 7.1 & 7.4 & 1.5 \\
\hline
\end{tabular}

Source: Giuliodori (2003).

\subsection{The history of VAR-methodology}

Vector autoregressions have become an important tool since Sims (1980) criticized large-scale macroeconometric models for assuming unfounded identifying restrictions. One of the main issues in the analysis of properties of vector autoregressions is the (use of theory in order to come to) identification of so-called structural shocks. Sims suggested solving the identification of the contemporaneous structure of the model by using a recursive (orthogonalized) structure. This implies that there is no contemporaneous feedback from the variables mentioned at the end of the ordering on the variables on top. Although theory can play a role in such a recursive scheme, the lack of simultaneity led Bernanke (1986), Blanchard and Watson (1986), and Sims (1986) to propose a larger role for economic theory in formulating plausible restrictions on contemporaneous interactions among variables. This implies that the recursivity can be replaced by other more simultaneous structures (at least conserving the number of identifying restrictions). This class of models is labelled Structural VAR (SVAR) models. Blanchard and Quah (1989) and Gali (1992) suggested to impose so-called long-run restrictions on impulse response functions to allow for instance for inflation not to have an impact on output. But, as Faust and Leeper (1997) argue, imposing longrun restrictions of this type requires the VAR to satisfy strong dynamic restrictions.

Pesaran and Shin (1998) criticized the orthogonal impulse-response analysis (Cholesky-decomposition) and advocated to use so-called generalized impulse-response analysis. These generalized impulse responses from an innovation to the $j^{\text {th }}$ variable are generated by applying a variable specific Cholesky factor computed with the $j^{t h}$ variable at the top of the ordering. These impulses therefore do not depend on the initial ordering of the vari- 
ables. A major disadvantage of the generalized impulse response analysis is that the results are completely a-theoretical and lack any obvious interpretation. The major advantage is that the shock patterns observed appeal more to historical data and covariations.

Following the Granger representation theorem vector autoregressions can easily be transformed into a so-called Vector Error Correction model (see Garratt et al., 2003). In a VECM apart from the standard lagged differenced dependent vectors, stationary linear combinations of the levels of the variables are added. These cointegrating vectors describe the long-run equilibrium of the model. It is obvious that economic theory is needed to identify these long-run vectors. Garratt et al. show that it is possible, at least in principle, to combine long-run VECM restrictions and short-run theoretical restrictions in the so-called SVAR.

There is a debate on the use of cointegrating relations in VAR-models. As Sims et al. (1990) showed, a VAR model of $I(1)$-variables can be estimated unrestricted (at least asymptotically) if there are sufficient cointegrated relations. Estimating a VECM with ill-specified (or arbitrarily chosen) longrun vectors will lead to biased impulse-response functions. Estimating the VAR in first-differenced stationary variables leads to a loss of information though. So the final choice between a model in $I(1)$ - or $I(0)$-form depends on making the rather subjective trade-off between a loss of information using $I(0)$-variables versus the chance of including meaningless long-run vectors.

\subsection{Identifying monetary policy shocks}

Identifying monetary policy shocks using times series information is not straightforward. One could simply observe the actions of monetary policy makers (e.g. policy interest rate increases), but policy makers respond to non-monetary developments. If the demand for goods increases and supply is fixed (as will be likely in the short run), an interest rate increase will reflect this demand change and not so much a monetary contraction. So one needs to know the structure of the economy in order to understand and interpret monetary shocks.

As Christiano et al. (1999) argue the literature explores three general strategies to isolate monetary policy shocks. The first uses economic identification to estimate central banks' feedback rules. Here one assumes that the monetary policy instrument, e.g. the policy interest rate, is well known and accepted, that the contemporaneous determinants of this policy rate are known, and that the dynamics of interaction between the policy rate and the other variables can be traced. One can directly estimate a forwardlooking monetary policy reaction function, like Rudebusch (1998) does for a Taylor-rule, or estimate a prototype VAR. Identification of monetary policy shocks can be performed by assuming orthogonalized shocks or by imposing structure in a SVAR (see Sims and Zha, 1995, or Bernanke and Mihov, 
1998). A second way to identify monetary policy shocks is to look at data like board meetings to try to distillate policy shocks (see Romer and Romer, 1989). A third method to identify shocks is to assume that they don't affect real variables in the long run (see Gali, 1992). As explained above, this approach has been criticized. In long-run models, like VECM's, no attention to monetary shocks is given.

There are numerous VAR-studies on monetary transmission. The basic interest in VAR-models indeed originated from the interest in monetary transmission and the Lucas-critique on large-scale structural modeling (all the references given above apply to this field). As Christiano et al. (1999) argue the models can be classified according to the specification of the monetary reaction function. Central banks can focus on monetary aggregates (M2, M3), interbank aggregates (like (non)-borrowed or total reserves, see Bernanke and Mihov, 1998), interest rates (like the Taylor-rule, Taylor, 1993) or even on the interaction between interest and exchange rates (see for instance Kim and Roubini, 2000, Cushman and Zha, 1997, and Clarida and Gertler, 1997).

In general terms one can argue that misspecification is a common theme in VAR-models. Misspecification can originate from a wrong interpretation of the art of monetary policy to the lack of including relevant variables. One of the common features of monetary VAR-models is the so-called price puzzle. In lots of postwar business cycles a rise in inflation was preceded by an increase in interest rates and commodity prices (see Eichenbaum, 1992). Leaving commodity prices out or ignoring indicators of future inflation leads to substantial price puzzles in numerous VAR-models. Barth and Ramey (2000) argue that the cost channel may be an important part of the monetary transmission mechanism. They argue that if working capital is an essential component of production and distribution, monetary contractions can affect output through a supply channel as well as the traditional demand-type channels. An increase in the interest rate will increase production costs and lower output. So, generally spoken, modern VAR-studies are not so much troubled by the price puzzle (after controlling for other demand and supply shocks).

\subsection{VAR-models and asset prices}

Both VAR models and Equilibrium Business Cycle models report substantial asset price (wealth) effects. For instance Lettau et al. (2002) report a strong wealth effect on consumption in the US using an SVAR-model. The IMF (2002) reports a robust international wealth effect, especially via equity prices in market-based economies. Bernanke et al. (1999) present a theoretical model that includes a so-called financial accelerator that can support the empirical findings. This model is extended with an equity market in Bernanke and Gertler (1999), while Aoki et al. (2002) include a housing 
market.

Besides the broad establishment of wealth effects there is a lively debate on the role of asset prices in monetary policy. The general notion in favour of including asset price fluctuations in monetary policy rules is that an asset price bubble is socially unwanted. The disruptive effects of the bursting of the bubble lead to real effects of various kinds (economic growth, investment, income distribution, soundness of the financial system), which should be avoided by a central bank. There are disadvantages of using monetary policy in trying to avoid bubbles though. As Dornbusch (1999) argues there are two major disadvantages. First, there is a tendency towards an asymmetric response to asset price changes. A sudden widespread slump in assets prices will lead to a large provision of liquidity. A central bank is concerned about trust in the financial system and wants to provide stability. An asset price boom should then lead to an increase in interest rates, but the general public will typically not appreciate this. Knowing the likely reaction of central banks, there will be a moral hazard problem that leads to overly risky investment, possibly creating a bubble. Secondly, the credibility of a central bank might be lowered. Asset prices are volatile and typically hard to predict. Responding on a day-to-day basis may reduce credibility.

The following items seem to be relevant is this discussion:

1. Should measures of the general price level include asset prices?

2. Should there be target levels for asset prices?

3. Should asset prices be included as indicators in a direct inflation strategy?

4. Should monetary policy makers react stronger to asset prices than item 3 prescribes?

The majority of opinions says no to the first two items. It is very hard to estimate the true value of individual stock for instance, so how could a central bank be able to value all assets appropriately? In the System of National Accounts it is common to measure price indices based on flow transactions in goods. Including prices of stocks of assets would blur this approach. Moreover, one could argue that if asset prices were relevant, they would be leading indicators in decisions. Moreover they can be leading indicators without being included in the indicators of the current general price level.

The empirical research on the third and fourth item can be divided into two competing views. On the one hand, papers by Bernanke and Gertler $(1999,2001)$ argue that a central bank should not respond to asset price fluctuations. On the other hand, Cecchetti et al. (2002) and Filardo (2001) come to the opposite conclusion. Bernanke and Gertler analyze the role of an exogenously determined flexible inflation-targeting rule in a sophisticated 
dynamic new-Keynesian model with credit market frictions. Their main idea is that if asset price changes are important they should translate into changes in expected inflation and via that channel have their impact on monetary policy. A central bank should not try to target asset prices. Cecchetti et al. argue that one should use an optimal monetary policy rule that takes into account all information. Ignoring asset price changes will lead to suboptimal outcomes. But a central bank should be able to distinguish asset price bubbles in the Cecchetti et al. model. Filardo (2001) argues that a central bank should respond to asset price movements as long as they provide some information about inflation or output, even if the prices are driven by bubbles or not. It should be clear though in the Filardo-model how asset price fluctuations affect real variables. If this is not clear, the expected costs of responding to asset price changes might be too high.

So both wealth effects and monetary policy reactions to asset price changes are found to be relevant and could possibly lead to better specifications of VAR-models. In principle three assets are used in empirical studies: equity, housing, and liquidity. We don't focus on liquidity here, but review some of the results found for equity transmission and housing market studies.

Ludvigson and Steindel (1999) analyze the impact of wealth on consumption. Using a VAR-model they find that there is a contemporaneous impact from wealth on consumption. Lettau et al. (2002) construct an SVAR for the US and include household asset wealth in a consumption model. They conclude that the impact of shocks to the Federal Funds Rate via wealth components is not so strong, but direct interest rate effects are. Asset values can be influenced by other sources (like price increases or upturn of the business cycle) and can be amplified into consumption.

Lastrapes (2002) estimates the dynamic response of aggregate owneroccupied housing prices to money supply shocks and interprets these responses using a dynamic equilibrium model of the housing market that relies on the asset view of housing demand. Money supply shocks are identified empirically from a vector autoregression. Using monthly data, he finds that money shocks have real effects on the housing market: both real housing prices and housing sales (new starts and existing homes) rise in the shortrun in response to positive shocks to the money supply. Giuliodori (2003) gives an extensive overview of the role of house prices in the Euro-countries. He estimates SVAR-models for several countries (Belgium, Finland, Ireland, Italy, the Netherlands, Spain, Sweden, and the UK) and links the results to facts of financial structure (like Cecchetti, 1999). Giuliodori includes inflation, GDP, real house prices, the interest rate and the exchange rate as the key variables. Iacoviello (2000) estimates VAR- models for six European economies to explain house price movements. He finds a substantial impact of monetary policy on house prices. Using a sample of France, Germany, Italy, Spain, Sweden, and the UK) Iacoviello specifies a five-dimensional 
VAR with output, real house prices, real money, a short-term interest rate and inflation. He finds that a contractionary monetary policy has a negative impact on real house prices (to a similar extent as output), especially in the UK and Italy (while moderate effects appear for Germany).

There are not so many VAR-studies that include equity prices. Goodhart and Hofmann (2001) is an exception. They assess the role of asset prices as information variables for aggregate demand conditions and in the transmission of monetary policy. By looking at reduced form coefficient estimates and VAR impulse responses Goodhart and Hofmann derive Financial Conditions Indices, weighted averages of the short-term real interest rate, the effective real exchange rate, real property and real share prices, for the G7 countries. They find that house and share prices get a substantial weight in such an index and that the derived Financial Conditions Indices contain useful information about future inflationary pressures. Elbourne and Salomons (2003) estimate an 8-variable VAR for developed economies and find no substantial equity wealth effects (except for the UK and Japan).

\subsection{VAR-models of Germany}

Many VAR-models for Germany have been developed. We limit ourselves here to review SVAR-models and models that focus on monetary transmission. In an early study Weber (1996) analyzes the determinants of the post-unification downturn in Germany using an SVAR-model. The results suggest that German business cycles were not all alike. Whilst adverse supply shocks clearly matter before unification, it is primarily adverse aggregate demand shocks and a too tight monetary policy, which dominate the German post-unification decline in output growth rates. Bernanke and Mihov (1997) apply a structural VAR to determine the historical optimal indicator of German monetary policy and find that the Lombard rate has historically been a good policy indicator. Peersman (2002) estimates an SVAR-model that links short and long run interest rates in Germany. He finds a positive correlation after a supply and demand shock and a negative correlation after a monetary policy shock. Kakes and Sturm (2002) analyze monetary policy transmission according to the credit channel by assuming heterogeneity between banks. Banks hold important positions in the German economy, which justifies such an approach.

There have been a number of VAR-studies on the EU-level that include the German case. In the Monetary Transmission Network of the European Central Bank Mojon and Peersman (2003) review VAR-models for 10 EUcountries. They classify the countries according to their monetary integration with Germany. Apart form the first class, Germany itself, there are core- Germany countries, like the Netherlands or Austria, and other EUcountries. Mojon and Peersman find output effects from a tighter monetary policy, falling prices and a rather common pattern across countries. Peers- 
man and Smets (2001) estimate an area-wide identified VAR for the euro area. They find for the EU similar effects as have been found in the analysis of US monetary policy. On the G-7 level Canova and De Nicolo (2002) examine the importance of monetary disturbances for cyclical fluctuations in real activity and inflation. They employ a novel identification approach, which uses the sign of the cross-correlation function in response to shocks to assign a structural interpretation to orthogonal innovations. They find that identified monetary shocks significantly contribute to output and inflation cycles in all G-7 countries.

\section{Vector Autoregression}

In this section we present our different Vector AutoRegressions (VARs). We first construct a basic VAR model, including output, prices, credit, the exchange rate and the interest rate as the key endogenous variables. Next we switch output for the IFO business climate indicator and add asset prices to illustrate their contribution. Overall, we follow the same methodology in the models. We estimate the VAR models using quarterly data from 1978.4 to 1989.4 and 1992.1 to 1998.4. So we exclude the German reunification period and end our sample at the start of the European Central Bank. We estimate Structural VAR (SVAR)-models in all cases. We focus on the interpretation of the Impuls-Response Functions as far as the impact of interest rate and asset prices shocks and variance-decompositions of the interest rate residuals concerning monetary policy. Data are taken from the EUROMON-source, produced by the Dutch central bank (see for a description of the data the appendix).

\subsection{A basic VAR-model}

First we estimate a basic five-variable VAR-model of the German economy for the 1978.4- 1998.4 sample (excluding the reunification period 1990.11991.4). This period covers the basic EMS-period. This VAR model includes reference series like GDP $(Y)$, the CPI $(P)$, real domestic credit to the private sector $(C R$, as the indicator of monetary stance), the nominal trade weighted exchange rate $(E)$, and the short-term money market interest rate $\left(R_{S}\right)$. We use the latter variable as the indicator of monetary policy. Identified shocks to the interest rate will be interpreted as monetary policy changes. Officially, this might not have been the monetary strategy of the Bundesbank, but de facto interest rate was used in the EMS-period as monetary policy variable (see also Bernanke and Mihov, 1997).

The dependent vector is $\left[Y, P, C R, E, R_{S}\right]$. All variables are in logs. We tested for stationarity of the series using a larger sample available in the data set: 1970.1-2000.4. Most series are found to be of order I(1), although the first difference of the log of the price level is a borderline case (see Table 
Table 5: Unit root test results

\begin{tabular}{lllllll}
\hline \multicolumn{5}{c}{ Levels } & \multicolumn{5}{c}{ Differences } \\
\hline Variable & ADF & $(c, t, n)$ & p-value & ADF & $(c, t, n)$ & p-value \\
\hline$Y$ & -2.893 & $(c, t, 4)$ & 0.169 & -4.294 & $(c, 3)$ & 0.001 \\
$P$ & -2.707 & $(c, t, 4)$ & 0.236 & -1.271 & $(3)$ & 0.187 \\
$C R$ & -2.059 & $(c, t, 1)$ & 0.563 & -10.069 & $(c, 1)$ & 0.000 \\
$P_{H}$ & -2.346 & $(c, t, 5)$ & 0.405 & -4.294 & $(4)$ & 0.002 \\
$P_{E Q}$ & -2.483 & $(c, t, 1)$ & 0.336 & -4.294 & $(c, 0)$ & 0.000 \\
$E$ & 2.184 & $(1)$ & 0.993 & -4.294 & $(0)$ & 0.000 \\
$R_{S}$ & -2.970 & $(c, 1)$ & 0.041 & & & \\
$W_{T}$ & -1.820 & $(c, t, 2)$ & 0.687 & -4.261 & $(c, 1)$ & 0.001 \\
$P_{C}$ & -2.893 & $(c, t, 4)$ & 0.169 & & & \\
$R_{U S}$ & -3.051 & $(c, 5)$ & 0.033 & & & \\
$I F O$ & -3.587 & $(c, 1)$ & 0.008 & & \\
Sample: $1970.1-2000.4$. & $c=$ intercept, $t=$ trend, $n=$ number of lags (following \\
\multicolumn{7}{c}{ the Schwartz-criterium). }
\end{tabular}

5). The interest rates are stationary in the sample 1970.1-2000.4, but nonstationary in the sample 1978.4-1998.4 (e.g. the German interest rate has a $p$-value of 0.139). Next we test for the number of cointegrating vectors. If we find a near to full rank we could follow the Sims et al. (1990) principle and estimate the model in levels. Both the Trace and the Maximum Eigenvalue test indicate two co-integrating vectors at the one percent confidence level. Given the fact that our sample is small we need to use the one percent levels to test for co-integration (see Cheung and Lai, 1993). This finding leads us to use a model in differences. We use the annual difference operator: $\Delta_{4}(x)=$ $x-x_{-4}$. All variables are stationary in this form (results not reported here, but available upon request), except again for the inflation rate $(p=0.188)$. Proceeding with the model in differences we loose some information by not using the levels. We included three exogenous variables in the VAR in order to capture world economic development: relevant world trade growth $\left(\Delta_{4}(W T)\right)$, world commodity inflation $\left(\Delta_{4}\left(P_{C}\right)\right)$, and annual change of the $\log$ of the U.S. short-term interest rate $\left(\Delta\left(R_{U S}\right)\right)$. Although Germany is a large economy, it will be dependent on world developments. Moreover, we might reduce the so-called price puzzle including a world commodity price index.

The ordering of the variables is relevant in a Cholesky factorization of the variance-covariance residual matrix. We assume that shocks to output are basically driven by supply elements, that prices are rather sticky, credit largely dependent on output changes and the single asset price, the exchange rate, endogenous to a large extent. The policy interest rate is assumed to be 
responding to all other variables in the system. Experimenting with the lag structure we found three lags. It is good to note that the lag-length criteria did not hint at one specific lag length due to the flatness of the optimization surface.

As explained above, there are various ways to represent the analysis of shocks in a VAR-model:

- one can compute the orthogonalized impulse response functions. This is the solution offered by Sims (1980) and is labelled the Cholesky decomposition.

- One can impose theoretical structure on the short-run contemporaneous impact and restrict the $B_{0}$-matrix to an identified matrix. This approach is known as the SVAR (see Bernanke, 1986).

- One can impose theoretical structure on the long-run impact of contemporaneous shocks. This is the approach proposed by Blanchard and Quah (1986) and Gali (1992), but criticized by Faust and Leeper (1997).

- One can impose 'realistic' shocks by so-called Generalized Impulse Response functions (see Pesaran and Shin, 1998). Realistic shocks are taken from the estimated variance-covariance matrix of the residuals. Using GIR's the ordering of the variable in the VAR becomes irrelevant.

Inspecting the variance-covariance matrix of the estimated residuals the covariance of the interest rate residuals with all other variables are rather large (especially the exchange rate residuals). This implies that imposing a structure on the $B_{0}$-matrix will change the IRF's. Ideally one would like to derive restrictions from a fully-fledged macroeconomic system. In practice however this is done infrequently (Gali, 1992, and Sims and Zha, 1997, being exceptions). Instead, the more widely used approach is to present commonly accepted restrictions based on broad classes of models. As a metric of appropriateness one uses the economic plausibility of the dynamic responses to shocks imposed.

We assume that output is fully determined by supply shocks (as can be found in Gali, 1992, and Kim and Roubini, 2000). Output does not respond on any financial variable, because in the short-run only technology will have an impact on production:

$$
\epsilon_{Y}=\alpha_{11} u_{Y}
$$

For inflation we assume that output and foreign price developments (e.g. via oil prices and changes in world economic) activity affect the domestic price development instantaneously. Inflation responds slowly to all other variables in the model. The latter assumption is also made by e.g. Kim and 
Roubini (2000), where domestic output affects inflation contemporaneously. Financial variables do not have a contemporaneous effect on output.

$$
\epsilon_{P}=\alpha_{21} u_{Y}+\alpha_{22} u_{P}
$$

Credit is assumed to be determined by demand for credit in the short run. A standard credit demand function is based on transactions and portfolio motives, here represented by output and the impact of the interest rate. Demand for credit is mainly based on domestic arguments, so we assume no contemporaneous influence of the exchange rate.

$$
\epsilon_{C R}=\alpha_{31} u_{Y}+\alpha_{33} u_{C R}+\alpha_{35} u_{R}
$$

The exchange rate is determined by output and interest rate shocks. Like Kim and Roubini (2000) we assume that interest rate and exchange rate shocks should be modelled interactively. We assume that the exchange rate does not respond to changes in domestic inflation instantaneously, since this information will be transmitted via the interest rate. Domestic output changes are used as signals of real activity and do have a contemporaneous impact (see Kim and Roubini, 2000). Domestic credit conditions typically have no impact on the exchange rate.

$$
\epsilon_{E}=\alpha_{41} u_{Y}+\alpha_{44} u_{E}+\alpha_{45} u_{R}
$$

Finally we assume that the Bundesbank responded to shocks in output, assets, and inflation (via a so-called Taylor rule, see Taylor, 1993):

$$
\epsilon_{R}=\alpha_{51} u_{Y}+\alpha_{52} u_{P}+\alpha_{53} u_{C R}+\alpha_{54} u_{E}+\alpha_{55} u_{R}
$$

We summarize Equations (1) to (5) in a system $\epsilon=B_{0} u$ :

$$
\left(\begin{array}{c}
\epsilon_{Y} \\
\epsilon_{P} \\
\epsilon_{C R} \\
\epsilon_{E} \\
\epsilon_{R}
\end{array}\right)=\left[\begin{array}{ccccc}
\alpha_{11} & 0 & 0 & 0 & 0 \\
\alpha_{21} & \alpha_{22} & 0 & 0 & 0 \\
\alpha_{31} & 0 & \alpha_{33} & 0 & \alpha_{35} \\
\alpha_{41} & 0 & 0 & \alpha_{44} & \alpha_{45} \\
\alpha_{51} & \alpha_{52} & \alpha_{53} & \alpha_{54} & \alpha_{55}
\end{array}\right]\left(\begin{array}{c}
u_{Y} \\
u_{P} \\
u_{C R} \\
u_{E} \\
u_{R}
\end{array}\right)
$$

Note that the structural model is overidentified with 1 degree of freedom. We can accept the overidentification using a $\chi^{2}$-test: the $p$-value is 0.564 . We do not give an interpretation to the parameters of the $B_{0}$-matrix, since the estimation itself cannot identify precise values in such a simultaneous system.

We analyze the results of this model in two ways. First, we calculate the Impulse-Response Functions to structural shocks. We give the results in Figure 1. In Figure $1 u_{Y}$ is represented by shock1, $u_{P}$ by shock2, etc. From Figure 1 one can observe that a structural interest rate shock only 

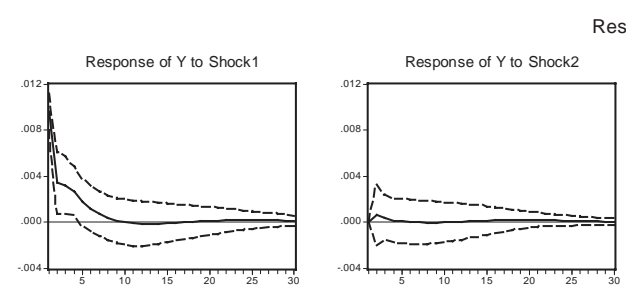

Response to Structural One S.D. Innovations \pm 2 S.E.
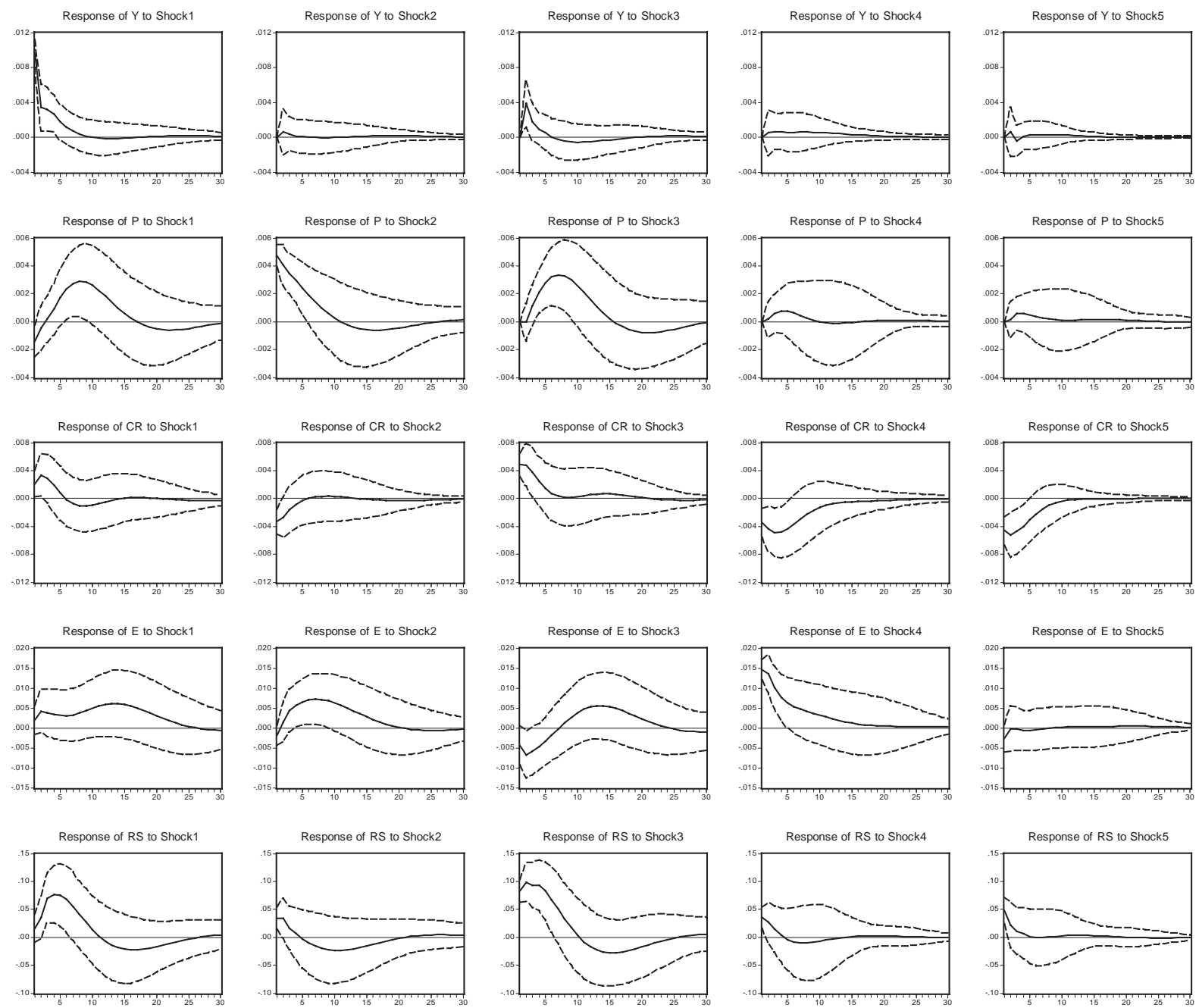

Figure 1: Impulse-Response-functions of the 5-variable model
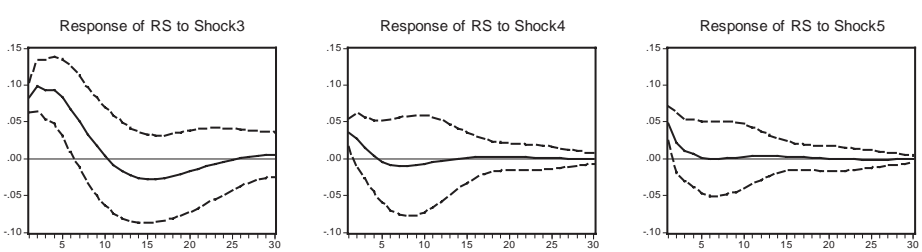
Table 6: Variance-Decomposition of interest rate residuals (SVAR)

\begin{tabular}{llllll}
\hline Period & $Y$ & $P$ & $C R$ & $E$ & $R_{S}$ \\
\hline 1 & 2.24 & 9.76 & 58.64 & 10.58 & 18.79 \\
4 & 22.79 & 4.82 & 63.05 & 4.10 & 5.24 \\
8 & 32.05 & 3.94 & 57.71 & 2.96 & 3.34 \\
12 & 31.72 & 6.09 & 55.93 & 3.03 & 3.23 \\
20 & 31.98 & 6.82 & 55.45 & 2.77 & 2.98 \\
\hline
\end{tabular}

affects credit, and not output or inflation. Credit shocks affect output and inflation. The interest rate responds to shocks in output and credit.

Next we present the Variance-Decomposition of the structural factorization for the interest rate shocks: these results shed light on the role of the variables in monetary policy (see Table 6 ). We can observe that output and credit are the crucial factors explaining the interest rate changes. This may be seen as a surprise, since it is widely accepted that the Bundesbank was more focused on inflation than on output. Apparently, credit takes the role of the monetary aggregate in describing monetary policy.

\subsection{The role of the IFO business climate indicator}

One of the basic issues in monetary VAR-models is the role of expectations. How does the central bank assess inflationary conditions and use its monetary policy instruments to correct any undesired developments? Suppose that, as Bernanke and Mihov (1997) argue, the Bundesbank followed an inflation targeting approach. In that case it is likely that it will have used not only inflationary forecasting devices, but also indicators of real economic activity, like the output gap. Following Taylor (1993) central banks are believed to respond on output gap and inflationary developments (the latter being more important in the German setting than in e.g. the U.S.). Given the information lag in (mostly revised) figures (see Orphanides, 2001) it is rather unlikely that the GDP-series takes this informational role. As Flaig and Plötscher (2001) illustrate, the IFO-indicator does carry an informational role in describing and predicting the German output gap.

In order to test for the value added of the IFO indicator we switch this variable for $\Delta_{4}(Y)$ in the base model. We again estimated the Structural VAR used above. The fit of the model improves (the $p$-value of the overidentification test increases to 0.747 ). The Impulse-Response Functions resemble those reported in Figure 1 closely and are not reported here. We confine ourselves to the Variance-Decompositions in order to assess the role of the IFO business climate indicator. In Table 7 it can bee seen that the IFO indicator gets a larger share in the decomposition than real GDP-growth in the previous model. The role of credit is reduced and inflation gets more 
Table 7: Variance-Decomposition of interest rate residuals (SVAR)

\begin{tabular}{llllll}
\hline Period & $Y$ & $P$ & $C R$ & $E$ & $R_{S}$ \\
\hline 1 & 0.05 & 8.98 & 62.81 & 10.70 & 17.47 \\
4 & 21.10 & 6.16 & 61.96 & 4.60 & 6.17 \\
8 & 43.26 & 9.18 & 38.90 & 5.16 & 3.50 \\
12 & 35.92 & 22.15 & 32.84 & 5.86 & 3.23 \\
20 & 40.40 & 20.09 & 32.78 & 4.55 & 2.19 \\
\hline
\end{tabular}

important. This finding seems to be more plausible. So, although the fit and the Impulse-Response Functions of this model and the base model are comparable, the IFO-model should be preferred.

\subsection{Extending the model with housing and equity prices}

Knowing the properties of the base model we extend the VAR-model with two additional variables: the house price index $P_{H}$ and the equity price $P_{E Q}$. Both housing and equity will affect consumption and investment behaviour (which we will roughly proxy here by GDP). So we extend our dependent vector to: $\left[Y, P, C R, P_{H}, P_{E Q}, E, R_{S}\right]$. We treat housing and equity similar to the asset price included in the model: the exchange rate. The other model properties remain the same: we use three lags, include the world commodity price index, the world trade index and the U.S. interest rate as exogenous variables. Testing for integration of the asset prices leads to the conclusion that both are stationary after differencing (see Table 5). Testing for cointegration reveals two co-integrating vectors at the 1 per cent confidence level, so we again estimate the model in annual differences using the 1978.4-1998.4 sample (skipping the reunification period). In the SVAR we treat the asset prices similar to the exchange rate in the base model, except for the contemporaneous impact of the housing and equity prices on real credit. Moreover we assume that housing, equity prices and the exchange rate are recursively influenced. This leaves a model with one overidentifying restriction (testing for overidentification yields a $p$-value of $0.288)$.

$$
\left(\begin{array}{c}
\epsilon_{Y} \\
\epsilon_{P} \\
\epsilon_{C R} \\
\epsilon_{P H} \\
\epsilon_{P E Q} \\
\epsilon_{E} \\
\epsilon_{R}
\end{array}\right)=\left[\begin{array}{ccccccc}
\alpha_{11} & 0 & 0 & 0 & 0 & 0 & 0 \\
\alpha_{21} & \alpha_{22} & 0 & 0 & 0 & & \\
\alpha_{31} & 0 & \alpha_{33} & 0 & 0 & 0 & \alpha_{37} \\
\alpha_{41} & 0 & \alpha_{43} & \alpha_{44} & 0 & 0 & \alpha_{47} \\
\alpha_{51} & 0 & \alpha_{53} & \alpha_{54} & \alpha_{55} & 0 & \alpha_{57} \\
\alpha_{61} & 0 & 0 & \alpha_{64} & \alpha_{65} & \alpha_{66} & \alpha_{67} \\
\alpha_{71} & \alpha_{72} & \alpha_{73} & \alpha_{74} & \alpha_{75} & \alpha_{76} & \alpha_{77}
\end{array}\right]\left(\begin{array}{c}
u_{Y} \\
u_{P} \\
u_{C R} \\
u_{P H} \\
u_{P E Q} \\
u_{E} \\
u_{R}
\end{array}\right)
$$




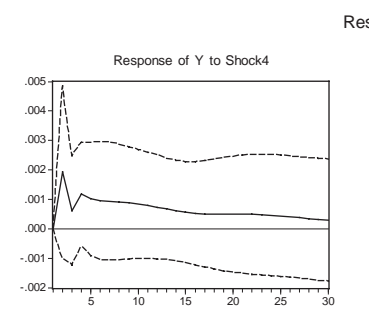

Response to Structural One S.D. Innovations \pm 2 S.E.
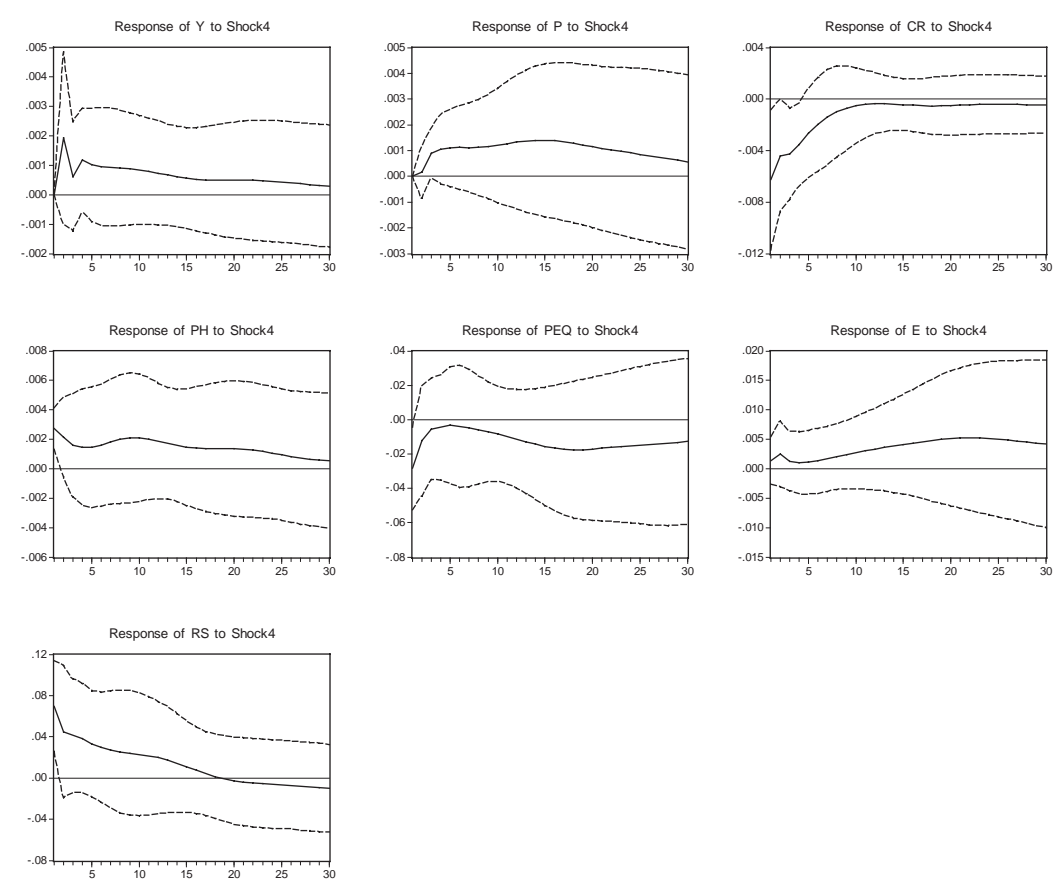

Figure 2: Impulse-Response-functions of a housing price shock

We analyze the model again in two ways. First, we plot the impulseresponse functions of the reactions to housing, equity, and interest rate shocks. Figures 2 to 4 present the responses to these shocks. From the housing price shock we observe a (non-significant) positive impact on output and the price level. It can also be observed that the interest rate increases, which reduces credit. The response to an equity price shock is quite different. Output and the price level stay rather constant, there is no interest rate response and credit even increases (probably to finance equity investment). Finally, we can clearly observe a contractionary response to an interest rate shock. If we compare this result with the results of the base model, the model extended with asset prices clearly gives more stylized results. Especially house prices suffer from an interest rate shock. Overall, there does not seem to be an equity channel in Germany.

We derive the impact of all structural shocks to unexplained variance of the monetary policy instrument equation: the short-term interest rate. Knowing the sources of this unexplained variance might help in deriving insight into the monetary policy reactions to shocks of various natures. Table 8 gives the contributions of the various shocks to the explanation of interest rate unexplained variance for various quarters. We observe that in the short 
Response to Structural One S.D. Innovations \pm 2 S.E.
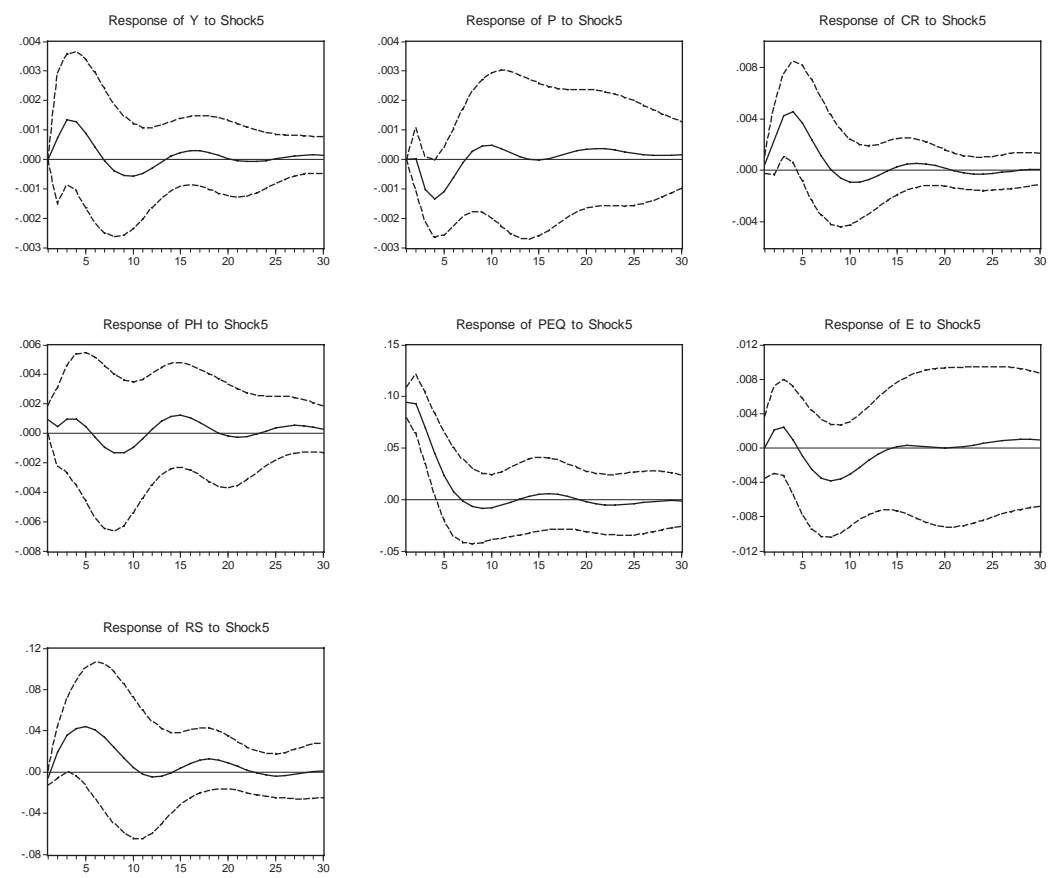

Figure 3: Impulse-Response-functions of an equity price shock 
Response to Structural One S.D. Innovations \pm 2 S.E.
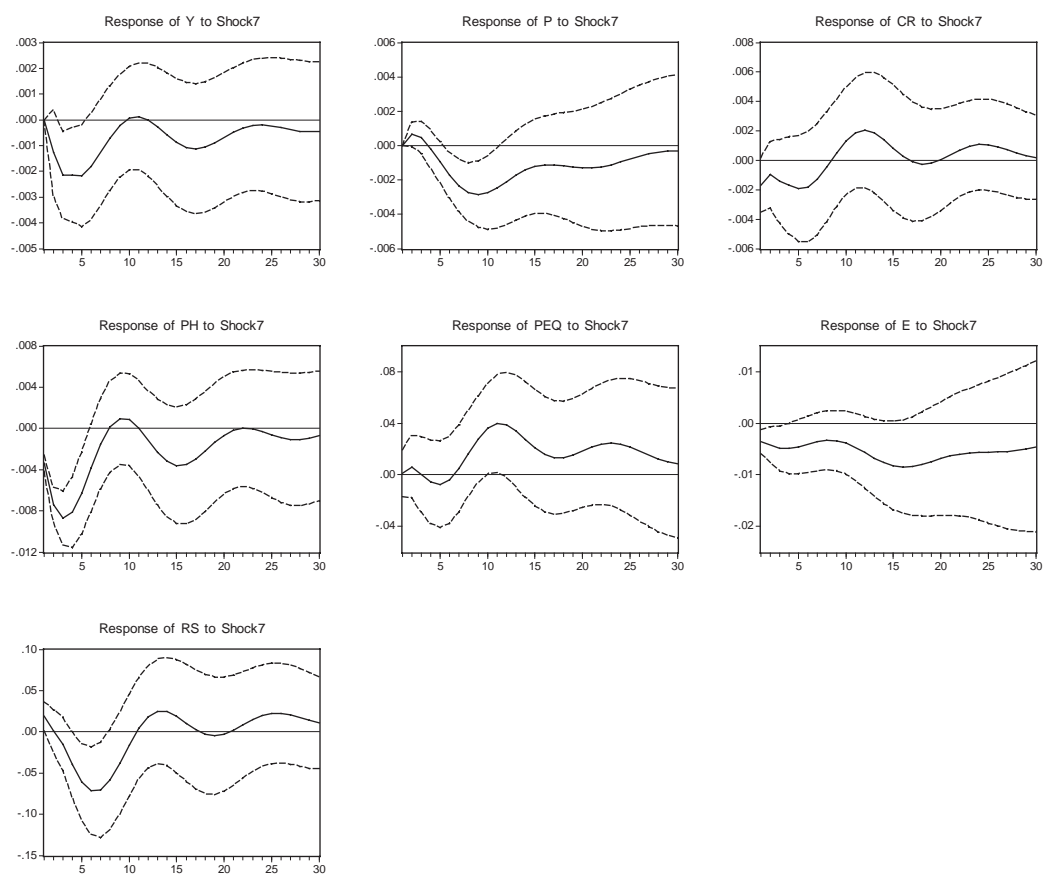

Figure 4: Impulse-Response-functions of an interest rate shock 
Table 8: Variance-Decomposition of interest rate residuals (SVAR)

\begin{tabular}{llllllll}
\hline Period & $Y$ & $P$ & $C R$ & $P_{H}$ & $P_{E Q}$ & $E$ & $R_{S}$ \\
\hline 1 & 0.54 & 5.08 & 41.06 & 48.65 & 0.27 & 0.92 & 3.50 \\
4 & 14.42 & 2.10 & 45.53 & 22.65 & 7.83 & 2.67 & 4.81 \\
8 & 38.66 & 1.30 & 24.08 & 14.93 & 9.77 & 9.46 & 21.34 \\
12 & 31.83 & 2.55 & 22.54 & 15.76 & 9.23 & 9.75 & 21.77 \\
20 & 24.37 & 3.60 & 22.72 & 15.52 & 9.28 & 9.33 & 22.16 \\
\hline
\end{tabular}

Table 9: Variance-Decomposition of interest rate residuals (SVAR) for the IFO-climate indicator

\begin{tabular}{llllllll}
\hline Period & $I F O$ & $P$ & $C R$ & $P_{H}$ & $P_{E Q}$ & $E$ & $R_{S}$ \\
\hline 1 & 0.96 & 5.06 & 44.48 & 46.91 & 0.00 & 0.54 & 2.03 \\
4 & 16.45 & 2.89 & 49.47 & 23.20 & 2.86 & 2.81 & 2.30 \\
8 & 38.87 & 3.99 & 22.16 & 11.62 & 1.76 & 10.86 & 10.73 \\
12 & 39.51 & 3.76 & 20.64 & 11.72 & 2.12 & 11.18 & 11.07 \\
20 & 38.63 & 3.35 & 18.43 & 10.35 & 3.80 & 10.26 & 13.17 \\
\hline
\end{tabular}

run housing shock variance is important. In the longer run real GDP and credit shocks become more relevant. There is no serious evidence that e.g. inflation has a large impact on monetary policy.

\subsection{Using the IFO business climate indicator and asset prices}

Finally, we combine the use of the IFO-climate indicator and housing and equity prices. So we again change the annual output growth rate with the IFOclimate indicator. We use the same structural model as presented above. The fit of the model improves using the IFO-climate indicator (the test on overidentification gets a $p$-value of 0.375 ). The impulse-response functions of housing, equity prices and interest rate shocks are largely comparable to the plots presented above. Using the IFO-climate indicator does not change the alleged role of housing and equity in this respect.

In Table 9 we present the variance-decompositions of the monetary policy equation using the IFO-climate indicator instead of GDP. Comparing Tables 9 and 8 we observe that the IFO-climate indicator takes a larger fraction to explain monetary policy shocks than output (as we expect). Housing prices remain important signalling variables, but equity is typically not. 


\section{Summary and conclusions}

In this paper we analyze the role of the IFO-climate indicator and asset prices in German monetary policy. The IFO-climate indicator is a forwardlooking indicator of output and should perform better than output itself in an analysis of monetary policy. Asset prices are believed to contain a large set of information and monetary policy should therefore include asset price information. We present a review of the theory of asset price transmission. Moreover, we illustrate that the German case is interesting to review, especially in terms of housing. The German housing market is relatively large compared to housing markets in other economies.

Using Structural Vector AutoRegression models we analyze the role of the IFO-climate indicator and asset price shocks. First we show that the IFO indicator contributes to describing monetary policy performed by the Bundesbank. Generally we find that the expected negative impact of an interest rate shock on output and the CPI is found in the model with asset price effects (and not so much in the model without). Analyzing housing and equity shocks reveals that house price shocks have a substantial impact on monetary responses. Equity price shocks are rather irrelevant in the German case, which comes as no surprise, given the institutional ordering of the German financial system. These conclusions hold for the model with GDP and the model with the IFO business climate indicator. Analyzing the variance decompositions of the various models shows that house prices have a serious impact on monetary policy. This impact is enforced using the IFO business climate indicator, which in itself explains more of monetary policy changes than output.

How should we take account of these results? First of all our results might contribute to the discussion on the use of instrument rules versus targeting rules. As Bernanke and Mihov (1997) show it seems that the Bundesbank used some kind of inflation targeting strategy. Our results basically confirm this view and point at house prices being a crucial variable. This result weakens the role of Taylor-rules, in which the full attention is given to output gaps and inflation itself in explaining monetary policy reactions.

Secondly and in line with the previous conclusion, one should have some concern about the large variety of variables influencing monetary policy in terms of the modeling strategy to analyze these effects. One cannot use a VAR-model of 20 variables over such a short time span. A suggestion made by Giannone et al. (2002) is to use factor analysis prior to going to a VAR- model. It is rather unlikely that in a high-dimensional VAR all the shocks will be independent. So Giannone et al. advocate using the principal components of all shocks. As we show in the German case, including a housing variable as one of the key shocks seems to be relevant.

Finally, a future avenue of research would be to analyze the housing 
market more in depth than we do in our reduced form model. Here one can think of a model in the spirit of Aoki et al. (2002) who present a dynamic stochastic general equilibrium model. This type of model could underpin the structure to identify the shocks in the short run, but also give directions to identify likely long-run effects. 


\section{Data Appendix}

We describe in short the sources of the data. For more information see Chirinko et al. (2003).

- CR: Bank credit to the private sector. In constant prices of 1990. IMF, International Financial Statistics. Nominal figures have been deflated by the private consumption deflator $P$.

- E: Nominal effective exchange rate. Index 1990=100. Exchange rates from Datastream. Weighted using calculated trade weights of 1990.

- $I_{B}^{R}$ : Investment in fixed assets of the business sector. In constant prices of 1990. Calculated as total investment in fixed assets minus residential investment and government investment. Source: $O E C D$ National Accounts and Quarterly National Accounts. We interpolated annual data for government investment and residential investment.

- IFO: IFO business climate index. See www.cesifo.de.

- $I_{H}^{R}$ : Residential investment. In constant prices of 1990. OECD Quarterly National Accounts. We interpolated annual data.

- $K_{B}$ : Market value of equity of the business sector. $K_{B}=K_{B}^{R} \frac{P_{E Q}}{100}$.

- $K_{B}^{R}$ : Real value of equity of the business sector. $K_{B}^{R}=K_{B}^{R}(-1)+$ $I_{B}^{R}-\delta K_{B}^{R}(-1)$, where we used an annualised depreciation rate $\delta=0.06$. Starting value derived from the sources of the $O E C D$, flows and stocks of fixed capital.

- $K_{H}$ : Market value of stock of private owner occupied houses. $K_{H}=$ $K_{H}^{R} \frac{P_{H}}{100}$.

- $K_{H}^{R}$ : Rebuilding value of stock of private owner occupied houses. $K_{H}^{R}=$ $K_{H}^{R}(-1)+I_{H}^{R}-\delta K_{H}^{R}(-1)$, where we used an annualised depreciation rate $\delta=0.02$. Starting value derived from $O E C D$, Flows and stocks of fixed capital.

- P: Deflator private consumption. Index 1990=100. Source: OECD National Accounts.

- $P_{C}$ : Price of commodities. In own currency, index 1990=100. Predenominated in dollars converted into national currencies using dollar exchange rates.

- $P_{E Q}:$ Share price index. Index 1990=100. IMF, International Financial Statistics. 
- $P_{H}$ : Residential property prices. Index 1990=100. Source: Bundesbank. Interpolation of annual prices in DEM 1000 of new or existing good quality 'Reihenhaus' in West-Germany.

- $R_{S}$ : Three-month deposit interest rate. In percentages. Source: De Nederlandsche Bank, Quarterly Bulletin.

- $R_{U S}$ : Three-month U.S. deposit interest rate. In percentages. Source: De Nederlandsche Bank, Quarterly Bulletin.

- WT: Relevant world trade. Volume index $1990=100$. Weighted import volumes of 12 other countries in the EUROMON data set, using calculated trade weights of 1990 .

- $Y$ : Gross domestic product. In constant prices of 1990. Source: OECD National Accounts. 


\section{References}

Adema, Y. (2003), "A Taylor rule for the euro area based on quasi-real time data", Research Memorandum WO 738, De Nederlandsche Bank.

Allen, F. and D. Gale, editors (2000), Comparing Financial Systems, MIT Press, Cambridge.

Aoki, K., J. Proudman, and G. Vlieghe (2002), "House prices, consumption, and monetary policy: a financial accelerator approach", Working Paper 169, Bank of England.

Barth, M.J. and V. Ramey (2000), "The cost channel of monetary transmission", Working Paper 7675, National Bureau of Economic Research.

Bernanke, B.S. (1986), "Alternative explanations of the money-income correlation", Carnegie-Rochester Series on Public Policy, 25, 49-99.

Bernanke, B.S. (2003), "Monetary policy and the stock market: some empirical results", Remarks At the Fall 2003 Banking and Finance Lecture, Widener University, Chester, Pennsylvania.

Bernanke, B.S. and A.S. Blinder (1988), "Credit, money, and aggregate demand", The American Economic Review, 78, 435-439.

Bernanke, B.S. and M. Gertler (1995), "Inside the black box: the credit channel of monetary policy transmission", Journal of Economic Perspectives, $\mathbf{9}, 27-48$.

Bernanke, B.S. and M. Gertler (1999), "Monetary policy and asset price volatility", in Federal Reserve Bank of Kansas City, editor, New Challenges for Monetary Policy, Proceedings of the 19th Jackson Hole Conference, Federal Reserve Bank of Kansas, Kansas City.

Bernanke, B.S. and M. Gertler (2001), "Should central banks respond to movements in asset prices?", The American Economic Review, Papers and Proceedings, 91, 254-257.

Bernanke, B.S., M. Gertler, and S. Gilchrist (1999), "The financial accelerator approach in a quantitative business cycle framework", in J.B. Taylor and M. Woordford, editors, Handbook of Macroeconomics, volume 1C, North-Holland, Amsterdam, 1341-1393.

Bernanke, B.S. and I. Mihov (1997), "Measuring monetary policy", Quarterly Journal of Economics, 113, 869-902.

Bernanke, B.S. and I. Mihov (1997), "What does the Bundesbank target?", European Economic Review, 46, 1025-1053.

Blanchard, O.J. and D. Quah (1989), "The dynamic effects of aggregate demand and supply disturbances", The American Economic Review, 79, 655-673. 
Blanchard, O.J. and M. Watson (1986), "Are business cycles all alike?", in R.J. Gordon, editor, The American Business Cycle: Continuity and Change, University of Chicago Press, Chicago, 123-165.

Brainard, W.C. and J. Tobin (1968), "Pitfalls in financial model building", The American Economic Review, 58, 99-122.

Canova, F. and G. de Nicolo (2002), "Monetary disturbances matter for business fluctuations in the G-7", Journal of Monetary Economics, 40, 1131-1159.

Cecchetti, S. (1999), "Legal structure, financial structure, and the monetary policy transmission mechanism", Economic Policy Review, Federal Reserve Bank of New York.

Cecchetti, S., H. Genberg, and S. Wadhani (2002), "Asset prices in a flexible inflation targeting framework", Paper presented at the conference on "Asset Price Bubbles: Implications for Monetary, Regulatory and International Policies", Federal Reserve Bank of Chicago/World Bank, Chicago.

Cheung, Y.W. and K.S. Lai (1993), "Finite sample sizes of Johansen's likelihood ratio tests for cointegration", Oxford Bulletin of Economics and Statistics, 55, 313-328.

Chirinko, R.S., L. de Haan, and E. Sterken (2003), "Should policymakers be concerned about asset prices?", Mimeo, De Nederlandsche Bank.

Christiano, L.J., M. Eichenbaum, and C.L. Evans (1999), "Monetary policy shocks: what have we learned and to what end?", in J.B. Taylor and M. Woordford, editors, Handbook of Macroeconomics, North-Holland, Amsterdam, 65-148.

Clarida, R. and M. Gertler (1997), "How the Bundesbank conducts monetary policy", in C.D. Romer and D.H. Romer, editors, Reducing inflation: motives and strategies, National Bureau of Economic Research, Chicago.

Cushman, D.O. and T. Zha (1997), "Identifying monetary policy in a small open economy under flexible exchange rates", Journal of Monetary Economics, 39, 433-448.

Dornbusch (1999), "Comments on Bernanke and Gertler", in Federal Reserve Bank of Kansas City, editor, New Challenges for Monetary Policy, Proceedings of the 19th Jackson Hole Conference, Federal Reserve Bank of Kansas, Kansas City.

Eichenbaum, M. (1992), "Comments: Interpreting the macroeconomic time series facts: the effects of monetary policy", European Economic Review, 36, 1001-1011.

Elbourne, A. and R. Salomons (2003), "Monetary transmission and equity markets in the EU", Mimeo, University of Groningen. 
Faust, J. and E. Leeper (1997), "When do long-run identifying restrictions give reliable results?", Journal of Business and Economic Statistics, 15, 345-353.

Filardo, A.J. (2001), "Should monetary policy respond to asset price bubbles? some experimental results", Working Paper 01-04, Federal Reserve Bank of Kansas City.

Flaig, G. and C. Plötscher (2001), "Estimating the output gap using business survey data", IFO Studien, 47, 221-232.

Gali, J. (1992), "How well does the IS-LM model fit the postwar U.S. data?", Quarterly Journal of Economics, 107, 709-738.

Garratt, A., K. Lee, M.H. Pesaran, and Y. Shin (2003), "A long-run structural macroeconometric model of the U.K. economy", The Economic Journal, 113, 412-455.

Giannone, D., L. Reichlin, and L. Sala (2002), "Tracking Greenspan: systematic and unsystematic monetary policy revisited", Mimeo, Free University of Brussels.

Giuliodori, M. (2003), Essays on the transmission mechanism of monetary policy, $\mathrm{PhD}$ thesis, University of Glasgow.

Goodhart, C.A.E. and R. Hofmann (2001), "Asset prices, financial conditions, and the transmission of monetary policy", Paper presented at a conference on "Asset Prices, Exchange Rates, and Monetary Policy", Stanford.

Iaccoviello, M. (2000), "House prices and the macroeconomy in Europe: results from a structural VAR analysis", Working Paper Series 18, European Central Bank.

IMF, editor (2000), World Economic Outlook, Spring, International Monetary Fund, New York.

Kakes, J. and J.-E. Sturm (2002), "Monetary policy and bank lending: evidence from German banking groups", Journal of Banking and Finance, 26, 2077-2092.

Kim, S. and N. Roubini (2000), "Exchange rate anomalies in the industrial countries: a solution with structural VAR approach", Journal of Monetary Economics, 45, 561-584.

Kiyotaki, N. and J. Moore (1999), "Credit cycles", Journal of Political Economy, 105, 211-248.

La Porta, R., F. Lopez de Silanes, and A. Shleifer (1999), "Corporate ownership around the world", Journal of Finance, 54, 471-517.

Lastrapes, W.D. (2002), "The real price of housing and money supply shocks: Time series evidence and theoretical simulations", Journal of Housing Economics, 11, 40-74. 
Lettau, M., S. Ludvigson, and C. Steindel (2002), "Monetary policy transmission through the consumption-wealth channel", Economic Policy Review, Federal Reserve Bank of New York.

Ludvigson, S. and C. Steindel (2002), "How important is the stock market effect on consumption?", Economic Policy Review, Federal Reserve Bank of New York.

Mojon, B. and G. Peersman (2003), "A VAR description of the effects of monetary policy in the individual countries of the euro area", in I. Angeloni, A. Kashyap, and B. Mojon, editors, Monetary policy Transmission in the Euro Area, Cambridge University Press, Cambridge.

Orphanides, A. (2001), "Monetary policy rules based on real-time data", The American Economic Review, 91, 964-985.

Peersman, G. (2002), "Monetary policy and long-term interest rates in Germany", Economics Letters, 77, 271-277.

Pesaran, M.H. and Y. Shin (1998), "Generalized impulse response analysis in linear models", Economics Letters, 58, 17-29.

Romer, C.D. and D.H. Romer (1989), "Does monetary policy matter? a new test in the spirit of Friedman and Schwartz", in O.J. Blanchard and S. Fischer, editors, NBER Macroeconomics Annual 1989, MIT Press, Cambridge.

Rudebusch, G. (1998), "Do measures of monetary policy in a VAR make sense?", International Economic Review, 39, 907-931.

Sauer, S. and J.-E. Sturm (2003), "Using Taylor rules to understand ECB monetary policy", Mimeo, IFO.

Sims, C.A. (1980), "Macroeconomics and reality", Econometrica, 48, 1-48.

Sims, C.A. (1986), "Are forecasting models usable for policy analysis?", Quarterly Review Winter, Federal Reserve Bank of Minneapolis.

Sims, C.A., J. Stock, and M. Watson (1990), "Inference in linear time series models with some unit roots", Econometrica, 58, 113-144.

Sims, C.A. and T. Zha (1995), "Does monetary policy generate recessions?", Mimeo, Yale University.

Taylor, J.B. (1993), "Discretion versus policy rules in practice", CarnegieRochester Series on Public Policy, 39, 195-214.

Walsh, C.A., editor (2003), Monetary Theory and Policy, 2nd edition, MIT Press, Cambridge.

Weber, A. (1996), "Germany before and after unification: a structural VAR analysis", Economic Modelling, 13, 575-601.

Wicksell, K. (1907), "The influence of the interest rate on prices", The Economic Journal, 17, 213-220. 


\section{CESifo Working Paper Series}

(for full list see www.cesifo.de)

1140 Michael Rauscher, Economic Growth and Tax-Competing Leviathans, February 2004

1141 Ernst Fehr and Jean-Robert Tyran, Money Illusion and Coordination Failure, February 2004

1142 Ingo Vogelsang, Network Utilities in the U.S. - Sector Reforms without Privatization, March 2004

1143 Marc-Andreas Muendler, Estimating Production Functions When Productivity Change is Endogenous, March 2004

1144 Sascha O. Becker, Samuel Bentolila, Ana Fernandes, and Andrea Ichino, Job Insecurity and Children's Emancipation, March 2004

1145 Pascalis Raimondos-Møller and Alan D. Woodland, Non-Preferential Trading Clubs, March 2004

1146 Robert Fenge and Matthias Wrede, EU Regional Policy: Vertical Fiscal Externalities and Matching Grants, March 2004

1147 Chi-Yung Ng and John Whalley, Geographical Extension of Free Trade Zones as Trade Liberalization: A Numerical Simulation Approach, March 2004

1148 Marc-Andreas Muendler, Trade, Technology, and Productivity: A Study of Brazilian Manufacturers, 1986-1998, March 2004

1149 Eugene Beaulieu, Vivek H. Dehejia, and Hazrat-Omar Zakhilwal, International Trade, Labour Turnover, and the Wage Premium: Testing the Bhagwati-Dehejia Hypothesis for Canada, March 2004

1150 Giorgio Brunello and Francesca Gambarotto, Agglomeration Effects on EmployerProvided Training: Evidence from the UK, March 2004

1151 S. Brock Blomberg, Gregory D. Hess, and Athanasios Orphanides, The Macroeconomic Consequences of Terrorism, March 2004

1152 Bodo Sturm and Joachim Weimann, Unilateral Emissions Abatement: An Experiment, March 2004

1153 Wolfgang Ochel, Welfare-to-Work Experiences with Specific Work-First Programmes in Selected Countries, March 2004

1154 Jan K. Brueckner and Eric Pels, European Airline Mergers, Alliance Consolidation, and Consumer Welfare, March 2004 
1155 Aaron Tornell, Frank Westermann, and Lorenza Martínez, NAFTA and Mexico's Economic Performance, March 2004

1156 George Economides, Sarantis Kalyvitis, and Apostolis Philippopoulos, Do Foreign Aid Transfers Distort Incentives and Hurt Growth? Theory and Evidence from 75 Aidrecipient Countries, March 2004

1157 Robert Fenge and Volker Meier, Are Family Allowances and Fertility-related pensions Siamese Twins?, March 2004

1158 Bruno S. Frey, Simon Luechinger, and Alois Stutzer, Valuing Public Goods: The Life Satisfation Approach, March 2004

1159 Jerome L. Stein and Guay C. Lim, Asian Crises: Theory, Evidence, Warning-Signals, March 2004

1160 Romain Ranciere, Aaron Tornell, and Frank Westermann, Crises and Growth: A ReEvaluation, March 2004

1161 Assaf Razin and Efraim Sadka, Transparency, Specialization and FDI, March 2004

1162 Ludger Woessmann, How Equal Are Educational Opportunities? Family Background and Student Achievement in Europe and the United States, March 2004

1163 B.M.S. van Praag and Barbara E. Baarsma, Using Happiness Surveys to Value Intangibles: The Case of Airport Noise, March 2004

1164 Aaron Tornell, Frank Westermann, and Lorenza Martínez, The Positive Link Between Financial Liberalization, Growth, and Crises, March 2004

1165 Helge Berger and Carsten Hefeker, One Country, One Vote? Labor Market Structure and Voting Rights in the ECB, March 2004

1166 Clemens Fuest and Martin Kolmar, A Theory of User-Fee Competition, March 2004

1167 Friedrich Schneider and Robert Klinglmair, Shadow Economies around the World: What Do We Know?, April 2004

1168 Horst Raff and Nicolas Schmitt, Exclusive Dealing and Common Agency in International Markets, April 2004

1169 M. Hashem Pesaran and Allan Timmermann, Real Time Econometrics, April 2004

1170 Sean D. Barrett, Privatisation in Ireland, April 2004

1171 V. Anton Muscatelli, Patrizio Tirelli and Carmine Trecroci, Can Fiscal Policy Help Macroeconomic Stabilisation? Evidence from a New Keynesian Model with Liquidity Constraints, April 2004 
1172 Bernd Huber and Marco Runkel, Tax Competition, Excludable Public Goods and User Charges, April 2004

1173 John McMillan and Pablo Zoido, How to Subvert Democracy: Montesinos in Peru, April 2004

1174 Theo Eicher and Jong Woo Kang, Trade, Foreign Direct Investment or Acquisition: Optimal Entry Modes for Multinationals, April 2004

1175 Chang Woon Nam and Doina Maria Radulescu, Types of Tax Concessions for Attracting Foreign Direct Investment in Free Economic Zones, April 2004

1176 M. Hashem Pesaran and Andreas Pick, Econometric Issues in the Analysis of Contagion, April 2004

1177 Steinar Holden and Fredrik Wulfsberg, Downward Nominal Wage Rigidity in Europe, April 2004

1178 Stefan Lachenmaier and Ludger Woessmann, Does Innovation Cause Exports? Evidence from Exogenous Innovation Impulses and Obstacles, April 2004

1179 Thiess Buettner and Johannes Rincke, Labor Market Effects of Economic Integration The Impact of Re-Unification in German Border Regions, April 2004

1180 Marko Koethenbuerger, Leviathans, Federal Transfers, and the Cartelization Hypothesis, April 2004

1181 Michael Hoel, Tor Iversen, Tore Nilssen, and Jon Vislie, Genetic Testing and Repulsion from Chance, April 2004

1182 Paul De Grauwe and Gunther Schnabl, Exchange Rate Regimes and Macroeconomic Stability in Central and Eastern Europe, April 2004

1183 Arjan M. Lejour and Ruud A. de Mooij, Turkish Delight - Does Turkey's accession to the EU bring economic benefits?, May 2004

1184 Anzelika Zaiceva, Implications of EU Accession for International Migration: An Assessment of Potential Migration Pressure, May 2004

1185 Udo Kreickemeier, Fair Wages and Human Capital Accumulation in a Global Economy, May 2004

1186 Jean-Pierre Ponssard, Rent Dissipation in Repeated Entry Games: Some New Results, May 2004

1187 Pablo Arocena, Privatisation Policy in Spain: Stuck Between Liberalisation and the Protection of Nationals' Interests, May 2004

1188 Günter Knieps, Privatisation of Network Industries in Germany: A Disaggregated Approach, May 2004 
1189 Robert J. Gary-Bobo and Alain Trannoy, Efficient Tuition Fees, Examinations, and Subsidies, May 2004

1190 Saku Aura and Gregory D. Hess, What's in a Name?, May 2004

1191 Sjur Didrik Flåm and Yuri Ermoliev, Investment Uncertainty, and Production Games, May 2004

1192 Yin-Wong Cheung and Jude Yuen, The Suitability of a Greater China Currency Union, May 2004

1193 Inés Macho-Stadler and David Pérez-Castrillo, Optimal Enforcement Policy and Firms' Emissions and Compliance with Environmental Taxes, May 2004

1194 Paul De Grauwe and Marianna Grimaldi, Bubbles and Crashes in a Behavioural Finance Model, May 2004

1195 Michel Berne and Gérard Pogorel, Privatization Experiences in France, May 2004

1196 Andrea Galeotti and José Luis Moraga-González, A Model of Strategic Targeted Advertising, May 2004

1197 Hans Gersbach and Hans Haller, When Inefficiency Begets Efficiency, May 2004

1198 Saku Aura, Estate and Capital Gains Taxation: Efficiency and Political Economy Consideration, May 2004

1199 Sandra Waller and Jakob de Haan, Credibility and Transparency of Central Banks: New Results Based on Ifo's World Economicy Survey, May 2004

1200 Henk C. Kranendonk, Jan Bonenkamp, and Johan P. Verbruggen, A Leading Indicator for the Dutch Economy - Methodological and Empirical Revision of the CPB System, May 2004

1201 Michael Ehrmann, Firm Size and Monetary Policy Transmission - Evidence from German Business Survey Data, May 2004

1202 Thomas A. Knetsch, Evaluating the German Inventory Cycle - Using Data from the Ifo Business Survey, May 2004

1203 Stefan Mittnik and Peter Zadrozny, Forecasting Quarterly German GDP at Monthly Intervals Using Monthly IFO Business Conditions Data, May 2004

1204 Elmer Sterken, The Role of the IFO Business Climate Indicator and Asset Prices in German Monetary Policy, May 2004 